medRxiv preprint doi: $h t t p s: / / d o i . o r g / 10.1101 / 2021.12 .30 .21267519$; this version posted January 1 , 2022. The copyright holder for this preprint (which was not certified by peer review) is the author/funder, who has granted medRxiv a license to display the preprint in It is made available under a CC-BY-NC-ND 4.0 International license .

\title{
Antibody binding and ACE2 binding inhibition is significantly reduced for the Omicron variant compared to all other variants of concern
}

Daniel Junker ${ }^{1, *}$, Matthias Becker ${ }^{1, *}$, Teresa R. Wagner ${ }^{1,2,{ }^{*}}$, Philipp D. Kaiser ${ }^{1}$, Sandra Maier ${ }^{1}$, Tanja M. Grimm¹, Johanna Griesbaum ${ }^{1}$, Patrick Marsall ${ }^{1}$, Jens Gruber $^{1}$, Bjoern Traenkle ${ }^{1}$, Constanze Heinzel ${ }^{3}$, Yudi T. Pinilla ${ }^{3}$, Jana Held ${ }^{3}$, Rolf Fendel $^{3,4,5}$, Andrea Kreidenweiss ${ }^{3,4,5}$, Annika Nelde,6,7,8, Yacine Maringer $6,7,8$, Sarah Schroeder ${ }^{7,9}$, Juliane S. Walz ${ }^{6,7,8,10}$, Karina Althaus ${ }^{11,12}$, Gunalp Uzun ${ }^{11}$, Marco Mikus $^{11}$, Tamam Bakchoul ${ }^{11,12}$, Katja Schenke-Layland ${ }^{1,8,13,14}$, Stefanie Bunk ${ }^{15}$, Helene Haeberle ${ }^{16}$, Siri Göpel ${ }^{4,15}$, Michael Bitzer ${ }^{15,17}$, Hanna Renk ${ }^{18}$, Jonathan Remppis $^{18}$, Corinna Engel ${ }^{18,19}$, Axel R. Franz ${ }^{18,19}$, Manuela Harries ${ }^{20}$, Barbora Kessel $^{20}$, Monika Strengert ${ }^{20,21}$, Gerard Krause ${ }^{20,21}$, Anne Zeck ${ }^{1}$, Ulrich Rothbauer ${ }^{1,2}$, Alex Dulovic ${ }^{1, \S, \#}$ and Nicole Schneiderhan-Marra1,§,\#

Author affiliations

1 - NMI Natural and Medical Sciences Institute at the University of Tuebingen, Reutlingen, Germany

2 - Pharmaceutical Biotechnology, University of Tuebingen, Tuebingen, Germany

3 - Institute of Tropical Medicine, University Hospital Tuebingen, Tuebingen, Germany

4 - German Center for Infection Research (DZIF), Partner Site Tuebingen, Tuebingen, Germany

5 - Centre de Recherches Médicales de Lambaréné (CERMEL), Gabon 
medRxiv preprint doi: https://doi.org/10.1101/2021.12.30.21267519; this version posted January 1, 2022. The copyright holder for this preprint (which was not certified by peer review) is the author/funder, who has granted medRxiv a license to display the preprint in It is made available under a CC-BY-NC-ND 4.0 International license .

6 - Clinical Collaboration Unit Translational Immunology, German Cancer

Consortium (DKTK), Department of Internal Medicine, University Hospital Tuebingen, Tuebingen, Germany

7 - Institute for Cell Biology, University of Tuebingen, Tuebingen, Germany

8 - Cluster of Excellence iFIT (EXC2180) "Image-Guided and Functionally Instructed Tumor Therapies", University of Tuebingen, Tuebingen, Germany

9 - Department of Otolaryngology, Head and Neck Surgery, University of Tuebingen, Tuebingen, Germany

10 - Dr. Margarete Fischer-Bosch Institute of Clinical Pharmacology and Robert Bosch Center for Tumor Diseases (RBCT), Stuttgart, Germany

11 - Center for Clinical Transfusion Medicine, Tuebingen, Germany

12 - Institute of Clinical and Experimental Transfusion Medicine, University Hospital Tuebingen, Tuebingen, Germany

13 - Institute of Biomedical Engineering, Department for Medical Technologies and

Regenerative Medicine, University of Tuebingen, Tuebingen, Germany

14 - Department of Medicine/Cardiology, University of California Los Angeles (UCLA), Los Angeles, USA

15 - Infectious Diseases, Department Internal Medicine I, University Hospital Tuebingen, Tuebingen, Germany

16 - Department of Anaesthesiology and Intensive Care Medicine, University Hospital Tuebingen, Tuebingen, Germany

17 - Center for Personalized Medicine, University of Tuebingen, Tuebingen, Germany 
medRxiv preprint doi: https://doi.org/10.1101/2021.12.30.21267519; this version posted January 1, 2022. The copyright holder for this preprint (which was not certified by peer review) is the author/funder, who has granted medRxiv a license to display the preprint in It is made available under a CC-BY-NC-ND 4.0 International license .

18 - University Children's Hospital, Tuebingen, Germany

19 - Center for Pediatric Clinical Studies, University Hospital Tuebingen, Tuebingen, Germany

20 - Helmholtz Center for Infection Research, Braunschweig, Germany

21 - TWINCORE, Centre for Experimental and Clinical Infection Research, a joint venture of Hannover Medical School and the Helmholtz Centre for Infection

Research, Hannover, Germany

* indicates shared first authorship

$\S$ indicates shared last authorship

\# indicates corresponding author

\section{Corresponding author Information}

Alex Dulovic - alex.dulovic@nmi.de, +49 (0)712151530 580

Nicole Schneiderhan-Marra - nicole.schneiderhan@nmi.de, +49 (0)712151530 815

\section{Keywords}

SARS-CoV-2, Omicron, B.1.1.529, antibody binding, ACE2, variant of concern 
medRxiv preprint doi: https://doi.org/10.1101/2021.12.30.21267519; this version posted January 1, 2022. The copyright holder for this preprint (which was not certified by peer review) is the author/funder, who has granted medRxiv a license to display the preprint in It is made available under a CC-BY-NC-ND 4.0 International license .

\section{Abstract}

The rapid emergence of the Omicron variant and its large number of mutations has led to its classification as a variant of concern (VOC) by the WHO(1). Initial studies on the neutralizing response towards this variant within convalescent and vaccinated individuals have identified substantial reductions(2-8). However many of these sample sets used in these studies were either small, uniform in nature, or were compared only to wild-type (WT) or, at most, a few other VOC. Here, we assessed IgG binding, (Angiotensin-Converting Enzyme 2) ACE2 binding inhibition, and antibody binding dynamics for the omicron variant compared to all other VOC and variants of interest (VOI)(9), in a large cohort of infected, vaccinated, and infected and then vaccinated individuals. While omicron was capable of binding to ACE2 efficiently, antibodies elicited by infection or immunization showed reduced IgG binding and ACE2 binding inhibition compared to WT and all VOC. Among vaccinated samples, antibody binding responses towards omicron were only improved following administration of a third dose. Overall, our results identify that omicron can still bind ACE2 while pre-existing antibodies can bind omicron. The extent of the mutations appear to inhibit the development of a neutralizing response, and as a result, omicron remains capable of evading immune control. 
medRxiv preprint doi: https://doi.org/10.1101/2021.12.30.21267519; this version posted January 1,2022 . The copyright holder for this

preprint (which was not certified by peer review) is the author/funder, who has granted medRxiv a license to display the preprint in It is made available under a CC-BY-NC-ND 4.0 International license .

\section{Main Text}

Since its initial outbreak in late 2019, SARS-CoV-2 has morphed into a global pandemic, characterised by waves of infection within countries and regions. Following the initial global wave, subsequent waves have often been triggered by the emergence of variants of concern that outcompeted earlier variants, which have increased transmission or show the ability to escape vaccine and infection-derived immunity (10-15). Several of these variants have been classified as variants of concern (VOC) by the WHO (9), with the delta variant currently being responsible for the majority of active infections globally (16). Due to concerns that its numerous spike protein mutations would render it able to escape immune control and its rapid spread in South Africa, the WHO classified omicron as a VOC on the $26^{\text {th }}$ of November 2021 (1). Within days of this classification, omicron had already been reported in multiple other countries and has now been shown to be responsible for increasing case numbers in South Africa(17), while also appearing to have a higher risk of reinfection(18). Early studies into neutralization against omicron have identified significant reductions in neutralizing activity, especially for those who have not received three vaccine doses $(2-4,19)$. However these studies have also often featured a low sample number, a limited diversity of sample types (e.g. only those vaccinated with Pfizer BNT162b2), or directly compared omicron to WT or a single other variant of concern. We provide here a comprehensive analysis of the binding capacity, binding dynamics and ACE2 binding inhibition of omicron towards antibodies generated through either vaccination or natural infection compared to WT and all other VOCs as well as the lambda and mu variants of interest (VOI). In contrast to these studies, we have included samples from a range of vaccines and dosing schemes currently available within the EU including boosters, and from 
medRxiv preprint doi: https://doi.org/10.1101/2021.12.30.21267519; this version posted January 1, 2022. The copyright holder for this preprint (which was not certified by peer review) is the author/funder, who has granted medRxiv a license to display the preprint in It is made available under a CC-BY-NC-ND 4.0 International license .

infected samples from both adults and children from the first, second and third waves in Germany.

We analyzed antibody binding responses towards omicron, all other variants of concern/interest and wild-type in sera from individuals with either vaccine-induced (vaccinated), naturally-induced (convalescent) or naturally-induced and vaccineboosted immunity (infected and vaccinated). We included samples from convalescent individuals from all three waves in Germany so far (first wave, WT $n=50$, second wave, alpha $n=30$, third wave, delta $n=6$ ), individuals vaccinated twice with two homologous doses of either mRNA-1273 $(n=46)$, AZD1222 $(n=60)$ or BNT162b2 $(n=60)$, individuals vaccinated twice with two heterologous doses of either AZD1222 and mRNA-1273 $(n=20)$ or BNT162b2 $(n=20)$, individuals vaccinated three times with BNT162b2 $(n=20)$ or individuals with a previous SARS-CoV-2 infection who were later vaccinated with a single dose of BNT162b2 $(n=25)$. As controls for unvaccinated individuals, commercially available pre-pandemic sera were used $(n=15)$. Please consult Table 1 for a full description of the characteristics of the samples used in this study.

Initially, we examined IgG binding using MULTICOV-AB(20), a previously published SARS-CoV-2 multiplex immunoassay that was adapted to analyze binding towards RBDs from all VOC/VOI (a full list of antigens analyzed and their mutations contained within can be found as Table 2). For both vaccinated and convalescent samples, IgG binding towards omicron from pre-existing antibodies was significantly reduced compared to WT (vaccinated $4.5 x$ fold decrease, infected 8.6 fold, Supplementary Table 1, Figure 1) and all other VOC/VOI (Figure 1a, Supplementary Table 2). By comparison, beta and mu which had the next largest decreases in IgG binding were only reduced 2.6-3.2 fold and 2.9-3.4 fold respectively (Supplementary Table 1). 
medRxiv preprint doi: https://doi.org/10.1101/2021.12.30.21267519; this version posted January 1, 2022. The copyright holder for this preprint (which was not certified by peer review) is the author/funder, who has granted medRxiv a license to display the preprint in It is made available under a CC-BY-NC-ND 4.0 International license .

Delta which currently still comprises the majority of global infections was reduced 1.21.3 fold compared to WT, and thus was still 3.5-6.3 fold greater than omicron (Supplementary Table 1 and 2). Next, we analyzed ACE2 binding inhibition as proxy for neutralization using RBDCoV-ACE2(21), a multiplex ACE2-RBD inhibition assay. This assay mimics the interaction between ACE2 and the RBD, analyzing the presence of antibodies which block said interaction, while the multiplex format allows for the simultaneous measurement of all VOCs/VUIs in a single well. To evaluate binding against other antigens of SARS-CoV-2, we also include the Spike and S1 domain of WT and the Spike of omicron. In contrast to IgG binding, ACE2 binding inhibition against the omicron RBD was substantially reduced compared to WT (omicron median $0-1.9 \%$, WT median $25.6-33.3 \%$ ), with only $4.5 \%$ of samples considered responsive (Figure 1b, Supplementary Table 3). By contrast, ACE2 binding inhibition for beta, gamma and mu which had the largest decreases relative to WT (median $8.8-8.9 \%$, median $8.3-10.0 \%$ and median $6.8-8.0 \%$ respectively), were still significantly more responsive compared to omicron. To confirm this lack of RBD binding, we analyzed the binding kinetics of RBD-specific antibodies from vaccinated (two dose BNT162b2) and convalescent (WT) study participants by biolayer interferometry (BLI) analysis (Figure 1c and d). Binding response and dissociation constant were measured for each sample as an indicator of amount and binding strength. Binding response towards the omicron RBD was reduced compared to both WT and delta (Figure 1c), while dissociation increased from WT to omicron for most samples (Figure 1d). While there was a large degree of variation among both the vaccinated and infected samples, omicron always had the lowest binding response (Supplementary Figure 1, Supplementary Table 3). When binding towards ACE2 itself was examined, omicron was still able to bind ACE2 with high affinity (Supplementary Figure 2). 
medRxiv preprint doi: https://doi.org/10.1101/2021.12.30.21267519; this version posted January 1, 2022. The copyright holder for this preprint (which was not certified by peer review) is the author/funder, who has granted medRxiv a license to display the preprint in It is made available under a CC-BY-NC-ND 4.0 International license .

As all other publications on neutralization against omicron had involved either pseudoviruses expressing the full-length spike $(2,5-7)$, or the native virus itself $(3,8$, 19), we analyzed omicron ACE2 binding inhibition against the Spike protein. Omicron ACE2 binding inhibition towards the Spike protein, while still significantly reduced compared to WT ( $p<0.001)$, was still present in $6.8 \%$ of samples $(4.5 \%$ for RBD) (Figure 2a). In contrast, IgG binding capacity towards the Spike was more conserved than the RBD (Figure 2 b-d).

Next, we analyzed whether vaccine type (AZD1222, mRNA-1273 or BNT162b2) and number of doses (homologous or heterologous 2 dose, or homologous 3 dose) received resulted in differences with respect to omicron binding response. To analyze how this response changed as time post-vaccination increased, we also compared the responses at 1-2 months post-second dose and 5-6 months post-second dose for the homologous recipients. IgG binding capacity at 5-6 months was low for all recipients regardless of the vaccine received, although homologous vector-based vaccination still resulted in lower binding responses than either mRNA-based or heterologous vaccination (Figure 3a). Among samples from 1-2 months post-dosing, infected and then vaccinated had the greatest IgG binding response (median=19.7), followed by two-dose mRNA-1273 (median=12.8), BNT162b2 (median=8.1) and AZD1222 (median=2.3). This pattern of decreasing responses as time post-dose increases remains consistent for ACE2 binding inhibition (Figure 3b). To determine whether a third dose results in increased binding responses against omicron, we analyzed samples from individuals who had received a third dose of BNT162b2 and compared it to those who had received their second dose in a similar timeframe, and individuals who would be eligible to now receive a third dose (Figure 3c, Supplementary Figures 3 and 4). Further boosting was associated with higher omicron ACE2 binding inhibition compared to two doses, suggesting that boosting 
medRxiv preprint doi: https://doi.org/10.1101/2021.12.30.21267519; this version posted January 1, 2022. The copyright holder for this preprint (which was not certified by peer review) is the author/funder, who has granted medRxiv a license to display the preprint in It is made available under a CC-BY-NC-ND 4.0 International license .

offers increased protection against omicron. However, this increase in protection was not limited to omicron and was present for all VOC (Figure 3c). Compared to the second dose from a similar timepoint, boosting with the third dose increased substantially confirming this effect is generated by the third dose itself, and not by time-post vaccination alone (Supplementary Figure 3 and 4).

Lastly, we analyzed whether natural infection with different variants resulted in differences in binding responses. There was no difference in ACE2 binding inhibition between convalescent individuals infected with either WT or alpha, with both having (Figure 3d) minimal inhibition against omicron. While some samples with a previous delta infection showed substantially more activity compared to WT or alpha, they had been collected much sooner after the infection (median dT 18 days) than WT (median dT 104 days) or alpha (median dT 88 days). To evaluate whether children's antibodies were more effective at binding towards omicron than adults, we compared convalescent samples 3-4 months post-PCR from the first wave in children $(n=20)$, to convalescent samples 3 months post-positive PCR from the same wave in adults $(n=30)$ (Figure $3 e$ and $\mathrm{f})$. There was no difference between adults and children in ACE2 binding inhibition (Figure 3e), although children did have significantly reduced binding capacity towards omicron $(p<0.001)$ (Figure $3 f)$.

In this study, we provide an in-depth characterization of antibody binding to omicron as compared to WT and all other VOCs and VUIs in a large diverse sample cohort. The use of an ACE2 inhibition assay enabled the comparison of multiple variants of interest simultaneously and was neutralizing antibody specific, while also producing comparable results to classical virus neutralization assays(21). Antibody binding towards the omicron variant elicited by either immunization or previous infection, is substantially reduced when compared with other variants. 
medRxiv preprint doi: https://doi.org/10.1101/2021.12.30.21267519; this version posted January 1, 2022. The copyright holder for this preprint (which was not certified by peer review) is the author/funder, who has granted medRxiv a license to display the preprint in It is made available under a CC-BY-NC-ND 4.0 International license .

Our data are in line with several other initial reports $(2-8,22)$ and provide additional information on IgG binding capacity and ACE2 binding inhibition by the inclusion of a large variety of sub-cohorts representing the present diversity of immunity against SARS-CoV-2, and by the comparison of the omicron variant to all other VOC/VOI. We found that both IgG binding capacity and ACE2 binding inhibition was more severely reduced for all samples against the omicron variant, than against any other VOC/NOI, with most samples being classified as non-responsive towards omicron for ACE2 binding inhibition. Like others $(4,5,7)$, we found that antibody binding responses towards omicron were significantly increased upon administration of booster dose. Boosting resulted in increases in both IgG binding capacity and ACE2 binding inhibition against all VOCs which is important given that delta currently remains the predominant global variant. However, caution should be applied to these results as it remains unknown if this increase in protection following the third dose changes as time post-administration increases. This increased protection following boosting also appears to apply for convalescent individuals, as seen by the increased IgG binding capacity and ACE2 binding inhibition for previously infected individuals who received a single dose, compared to those who had received any two vaccine doses. This increase in responses for individuals who have been both infected and vaccinated is in agreement with (23), who found that infections prior to vaccination resulted in a greater breadth of immune response, while (6) found that breakthrough delta infections among vaccinated individuals acted like a booster dose. Thus both reinfection and a booster dose leads to appropriate affinity maturation of elicited antibodies.

Our results are in agreement that either vaccine protection from two doses or natural immunity generated by a previous infection, appears broadly ineffective against omicron (18). Among those who had received two doses, binding responses were 
medRxiv preprint doi: https://doi.org/10.1101/2021.12.30.21267519; this version posted January 1, 2022. The copyright holder for this preprint (which was not certified by peer review) is the author/funder, who has granted medRxiv a license to display the preprint in It is made available under a CC-BY-NC-ND 4.0 International license .

consistent with other reports (2) in identifying a significant decrease for those who received homologous two-dose vector vaccination as opposed to homologous mRNA vaccination or heterologous vaccination.

We identified no difference in binding response for children compared to adults. While previous research has identified that children's antibody titres are higher than adults following infection (24), this did not result in an increase in binding capacity or ACE2 binding inhibition toward omicron. However, a limitation of our study is that the children and adult groups were not well-matched in terms of time post-positive PCR (median dT 104 for adults, 124 for children) or disease severity (majority hospitalized adults versus asymptomatic/light symptoms children). A larger investigation including vaccinated samples from children is needed to investigate any possible protective effect from previous infection and the antibody response towards Omicron itself in children in more detail.

Similarly to (22), we identified the same pattern of a much less pronounced reduction in RBD IgG binding response compared to RBD-directed neutralizing activity. Our analysis of both the Spike and RBD derived ACE2 binding inhibition suggests that this is consistent for both. Given that the Spike-derived antibodies had the same pattern of decreased neutralizing activity compared to IgG binding response, this suggests that while both epitopes are sufficiently conserved to enable binding, their divergent mutated sequences affect their neutralizing response. Further investigation into this pattern and particularly the role of S1-derived antibodies in neutralization is required to understand the neutralizing protection offered against omicron.

Overall, our results identify that while omicron can still can bind ACE2 and preexisting antibodies can bind omicron, the extent of the mutations within the RBD appear to be too divergent to enable RBD-directed antibodies to mount a neutralizing 
medRxiv preprint doi: https://doi.org/10.1101/2021.12.30.21267519; this version posted January 1, 2022. The copyright holder for this preprint (which was not certified by peer review) is the author/funder, who has granted medRxiv a license to display the preprint in It is made available under a CC-BY-NC-ND 4.0 International license .

response. While antibodies against the Spike protein have increased IgG binding capacity, they also have a significantly reduced neutralizing activity. The dramatic reductions in both IgG binding and ACE2 binding inhibition towards omicron as opposed to other VOC/VOI, confirm this variant remains capable of immune escape and requires careful sequence monitoring to identify any further sequence evolution. Importantly, booster doses elicit a significant increase in antibody response which correlates with a significant increase in both IgG binding and ACE2 binding inhibition against omicron. Our data adds weight a growing body of evidence that the continuous adaptation of vaccines to novel highly contagious variants needs to be considered in order to eliminate SARS-CoV-2. 
medRxiv preprint doi: https://doi.org/10.1101/2021.12.30.21267519; this version posted January 1, 2022. The copyright holder for this preprint (which was not certified by peer review) is the author/funder, who has granted medRxiv a license to display the preprint in It is made available under a CC-BY-NC-ND 4.0 International license .

\section{Conflicts of Interest}

NSM was a speaker at previous Luminex user meetings. The NMI is involved in applied research projects as a fee for services with the Luminex Corporation. All other authors declare no competing interests.

\section{Author contributions}

DJ, MaB, AD and NSM conceived the study. DJ, MaB, TRW, SM, AZ, UR, AD and NSM planned experiments. AD and NSM supervised the study. DJ, MaB, PDK, TRW, SM, TG, JoG, PM, JeG and BT performed experiments. CH, YTP, JH, RF, AK, AN, YM, SS, JSW, KA, GU, MM, TB, KSLSB, HH, SG, MiB, HR, JR, CE, ARF, MH, BK, MS and GK collected samples or organised their collection. KSL and NSM obtained funding. MaB and $A D$ performed data analysis and generated the figures. AD wrote the first draft of the manuscript. All authors approved the manuscript prior to submission.

\section{Acknowledgements}

We would like to thank other members of the Multiplex Immunoassays, Biological Development Center and Bioanalytics groups at the NMI for their support on this project. We would like to thank Ann Kathrin Horlacher and Mareike Walenta for assistance with sample processing and patient material storage. We Ulrike Schmidt, Iris Schaefer, Richard Schaad and Hannah Zug for technical support. We thank Katharina Kienzle, Hartmut Mahrhofer, Hardy Richter, Stefanie Döbele for help with sample collection. We thank Andrea Evers-Bischoff, Andrea Bevot and the CPCS at the University Hospital Tuebingen for organizational support in conducting the study. 
medRxiv preprint doi: https://doi.org/10.1101/2021.12.30.21267519; this version posted January 1, 2022. The copyright holder for this preprint (which was not certified by peer review) is the author/funder, who has granted medRxiv a license to display the preprint in It is made available under a CC-BY-NC-ND 4.0 International license .

We would like to thank all those involved in the organisation of the MuSPAD and TuSeRe sample collection. This work was financially supported by the State Ministry of Baden-Württemberg for Economic Affairs, Labour and Housing Construction (grant numbers FKZ 3-4332.62-NMI-67 and FKZ 3-4332.62-NMI-68), the Initiative and Networking Fund of the Helmholtz Association of German Research Centres (grant number SO-96), the EU Horizon 2020 research and innovation program (grant agreement number 101003480 - CORESMA). The funders had no role in study design, data collection and analysis, decision to publish, or preparation of the manuscript. 
medRxiv preprint doi: https://doi.org/10.1101/2021.12.30.21267519; this version posted January 1, 2022. The copyright holder for this preprint (which was not certified by peer review) is the author/funder, who has granted medRxiv a license to display the preprint in It is made available under a CC-BY-NC-ND 4.0 International license .

\section{References}

1. WHO. Classification of Omicron (B.1.1.529): SARS-CoV-2 Variant of Concern https://www.who.int/news/item/26-11-2021-classification-of-omicron-(b.1.1.529)-sarscov-2-variant-of-concern: WHO; 2021 [updated 26 November 2021. Available from: https://www.who.int/news/item/26-11-2021-classification-of-omicron-(b.1.1.529)-sars$\underline{\text { cov-2-variant-of-concern. }}$

2. Schmidt F, Muecksch F, Weisblum Y, Silva JD, Bednarski E, Cho A, et al. Plasma neutralization properties of the SARS-CoV-2 Omicron variant. medRxiv. 2021:2021.12.12.21267646.

3. Nemet I, Kliker L, Lustig Y, Zuckerman NS, Erster O, Cohen C, et al. Third BNT162b2 vaccination neutralization of SARS-CoV-2 Omicron infection. medRxiv. 2021:2021.12.13.21267670.

4. Garcia-Beltran WF, St. Denis KJ, Hoelzemer A, Lam EC, Nitido AD, Sheehan ML, et al. mRNA-based COVID-19 vaccine boosters induce neutralizing immunity against SARS-CoV-2 Omicron variant. medRxiv. 2021:2021.12.14.21267755.

5. Gruell H, Vanshylla K, Tober-Lau P, Hillus D, Schommers P, Lehmann C, et al. mRNA booster immunization elicits potent neutralizing serum activity against the SARS-CoV-2 Omicron variant. medRxiv. 2021:2021.12.14.21267769.

6. Lechmere T, Snell LB, Graham C, Seow J, Shalim ZA, Charalampous T, et al. Broad neutralization of SARS-CoV-2 variants, including omicron, following breakthrough infection with delta in COVID-19 vaccinated individuals. medRxiv. 2021:2021.12.01.21266982.

7. Doria-Rose N, Shen X, Schmidt SD, Dell S, McDanal C, Feng W, et al. Booster of mRNA-1273 Strengthens SARS-CoV-2 Omicron Neutralization. medRxiv. 2021:2021.12.15.21267805. 
medRxiv preprint doi: https://doi.org/10.1101/2021.12.30.21267519; this version posted January 1, 2022. The copyright holder for this preprint (which was not certified by peer review) is the author/funder, who has granted medRxiv a license to display the preprint in It is made available under a CC-BY-NC-ND 4.0 International license.

8. Wilhelm A, Widera M, Grikscheit K, Toptan T, Schenk B, Pallas C, et al. Reduced Neutralization of SARS-CoV-2 Omicron Variant by Vaccine Sera and Monoclonal Antibodies. medRxiv. 2021:2021.12.07.21267432.

9. WHO. Tracking SARS-CoV-2 variants

\section{https://www.who.int/en/activities/tracking-SARS-CoV-2-variants/ [}

10. Korber B, Fischer WM, Gnanakaran S, Yoon H, Theiler J, Abfalterer W, et al. Tracking Changes in SARS-CoV-2 Spike: Evidence that D614G Increases Infectivity of the COVID-19 Virus. Cell. 2020;182(4):812-27.e19.

11. Graham MS, Sudre CH, May A, Antonelli M, Murray B, Varsavsky T, et al. Changes in symptomatology, reinfection, and transmissibility associated with the SARS-CoV-2 variant B.1.1.7: an ecological study. The Lancet Public Health.

12. Davies NG, Abbott S, Barnard RC, Jarvis Cl, Kucharski AJ, Munday JD, et al. Estimated transmissibility and impact of SARS-CoV-2 lineage B.1.1.7 in England. Science. 2021;372(6538):eabg3055.

13. Collier DA, De Marco A, Ferreira IATM, Meng B, Datir R, Walls AC, et al. Sensitivity of SARS-CoV-2 B.1.1.7 to mRNA vaccine-elicited antibodies. Nature. 2021.

14. Tao K, Tzou PL, Nouhin J, Gupta RK, de Oliveira T, Kosakovsky Pond SL, et al. The biological and clinical significance of emerging SARS-CoV-2 variants. Nature Reviews Genetics. 2021;22(12):757-73.

15. Pegu A, O'Connell SE, Schmidt SD, O'Dell S, Talana CA, Lai L, et al. Durability of mRNA-1273 vaccine-induced antibodies against SARS-CoV-2 variants. Science. 2021;373(6561):1372-7.

16. CoVariants. Shared Mutations (https://covariants.org/shared-mutations) [ 17. Karim SSA, Karim QA. Omicron SARS-CoV-2 variant: a new chapter in the COVID-19 pandemic. The Lancet. 2021;398(10317):2126-8. 
medRxiv preprint doi: https://doi.org/10.1101/2021.12.30.21267519; this version posted January 1, 2022. The copyright holder for this preprint (which was not certified by peer review) is the author/funder, who has granted medRxiv a license to display the preprint in It is made available under a CC-BY-NC-ND 4.0 International license .

18. Pulliam JRC, van Schalkwyk C, Govender N, von Gottberg A, Cohen C, Groome MJ, et al. Increased risk of SARS-CoV-2 reinfection associated with emergence of the Omicron variant in South Africa. medRxiv.

2021:2021.11.11.21266068.

19. Cele S, Jackson L, Khoury DS, Khan K, Moyo-Gwete T, Tegally H, et al. SARS-CoV-2 Omicron has extensive but incomplete escape of Pfizer BNT162b2 elicited neutralization and requires ACE2 for infection. medRxiv. 2021:2021.12.08.21267417.

20. Becker M, Strengert M, Junker D, Kaiser PD, Kerrinnes T, Traenkle B, et al. Exploring beyond clinical routine SARS-CoV-2 serology using MultiCoV-Ab to evaluate endemic coronavirus cross-reactivity. Nature Communications. 2021;12(1):1152.

21. Junker D, Dulovic A, Becker M, Wagner TR, Kaiser PD, Traenkle B, et al. COVID-19 patient serum less potently inhibits ACE2-RBD binding for various SARSCoV-2 RBD mutants. medRxiv. 2021:2021.08.20.21262328.

22. Carreno JM, Alshammary H, Tcheou J, Singh G, Raskin A, Kawabata H, et al. Activity of convalescent and vaccine serum against a B.1.1.529 variant SARS-CoV-2 isolate. medRxiv. 2021:2021.12.20.21268134.

23. Goel RR, Apostolidis SA, Painter MM, Mathew D, Pattekar A, Kuthuru O, et al. Distinct antibody and memory B cell responses in SARS-CoV-2 naïve and recovered individuals following mRNA vaccination. Sci Immunol. 2021;6(58).

24. Renk H, Dulovic A, Becker M, Fabricius D, Zernickel M, Junker D, et al. Typically asymptomatic but with robust antibody formation: Children's unique humoral immune response to SARS-CoV-2. medRxiv. 2021:2021.07.20.21260863. 
medRxiv preprint doi: https://doi.org/10.1101/2021.12.30.21267519; this version posted January 1, 2022. The copyright holder for this preprint (which was not certified by peer review) is the author/funder, who has granted medRxiv a license to display the preprint in It is made available under a CC-BY-NC-ND 4.0 International license .

25. Becker M, Dulovic A, Junker D, Ruetalo N, Kaiser PD, Pinilla YT, et al.

Immune response to SARS-CoV-2 variants of concern in vaccinated individuals.

Nature Communications. 2021;12(1):3109. 
medRxiv preprint doi: https://doi.org/10.1101/2021.12.30.21267519; this version posted January 1,2022 . The copyright holder for this preprint (which was not certified by peer review) is the author/funder, who has granted medRxiv a license to display the preprint in It is made available under a CC-BY-NC-ND 4.0 International license .

\section{Figures}

Figure 1 - Antibody binding response is significantly reduced for Omicron compared to all other variants of concern.
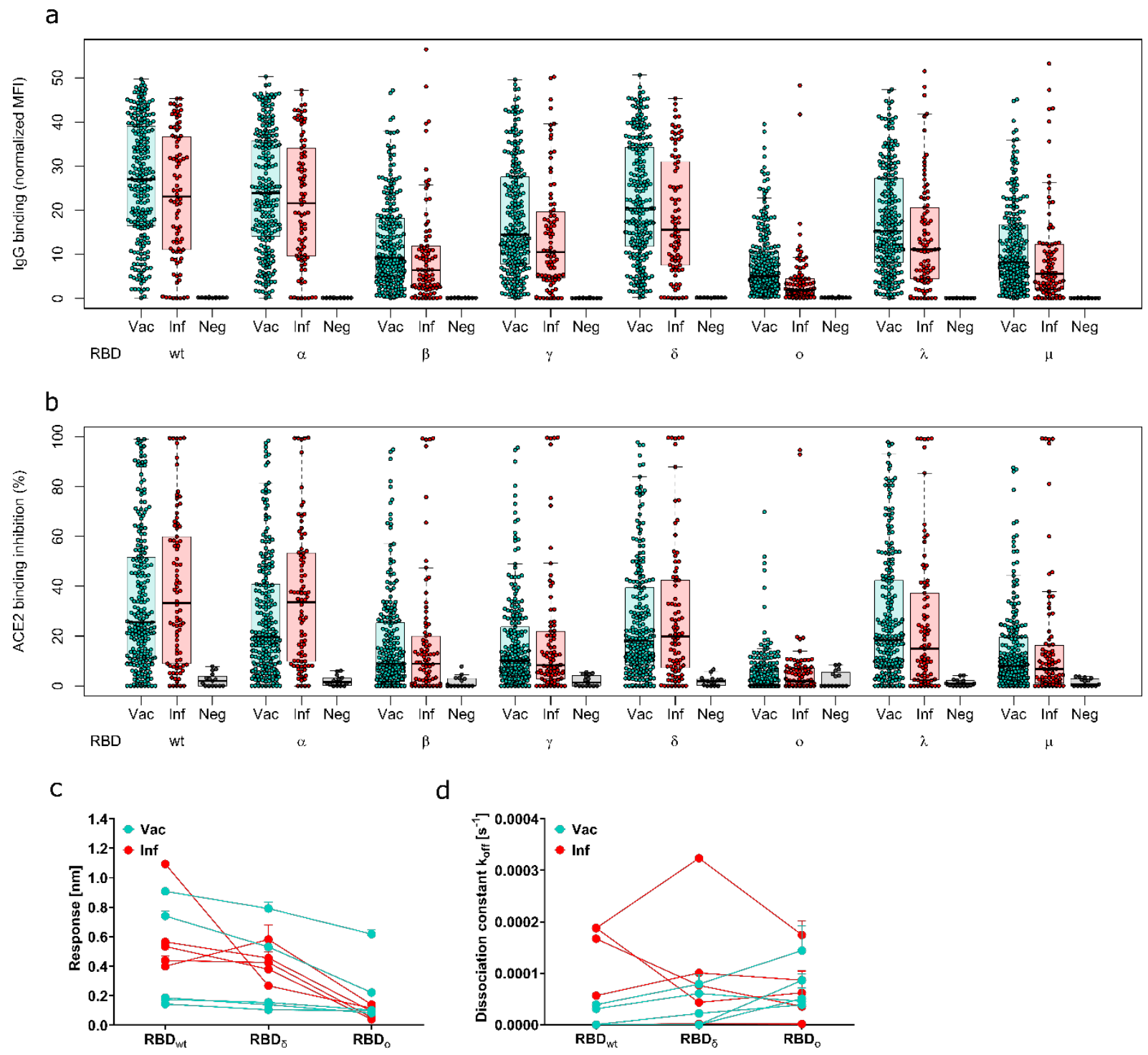

Binding response by pre-existing antibodies generated through either infection or vaccination was measured with MULTICOV-AB (a), RBDCoV-ACE2 (b) and Biolayer interferometry (c and d). (a) Boxplot showing that IgG binding is significantly reduced for omicron compared to all other variants of concern for both infected $(n=86)$ and vaccinated samples $(n=226)$. Negative samples are included as controls $(n=15)$. (b) Boxplot showing that ACE2 binding inhibition is significantly reduced for Omicron 
medRxiv preprint doi: https://doi.org/10.1101/2021.12.30.21267519; this version posted January 1, 2022. The copyright holder for this preprint (which was not certified by peer review) is the author/funder, who has granted medRxiv a license to display the preprint in It is made available under a CC-BY-NC-ND 4.0 International license .

compared to all other variants of concern for both infected and vaccinated samples.

Boxes represent the median, $25^{\text {th }}$ and $75^{\text {th }}$ percentiles, whiskers show the largest and smallest non-outlier values. Outliers were determined by 1.5 IQR. (c and d) Binding kinetics of RBD specific antibodies from serum samples of convalescent and vaccinated individuals (both $n=5$ ). Binding response $(c)$ and dissociation constant $(d)$ were determined by 1:1 fitting model of the individual serum samples between the different RBD variants. 
medRxiv preprint doi: https://doi.org/10.1101/2021.12.30.21267519; this version posted January 1, 2022. The copyright holder for this preprint (which was not certified by peer review) is the author/funder, who has granted medRxiv a license to display the preprint in It is made available under a CC-BY-NC-ND 4.0 International license.

Figure 2 - Both the Omicron RBD and Spike protein have minimal neutralizing activity.

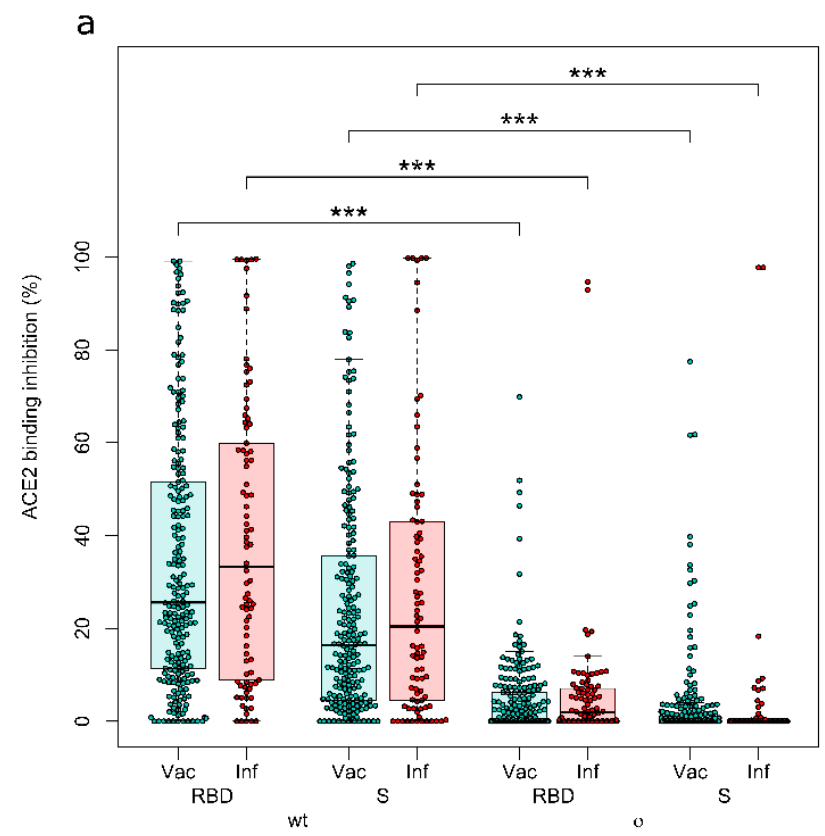

b
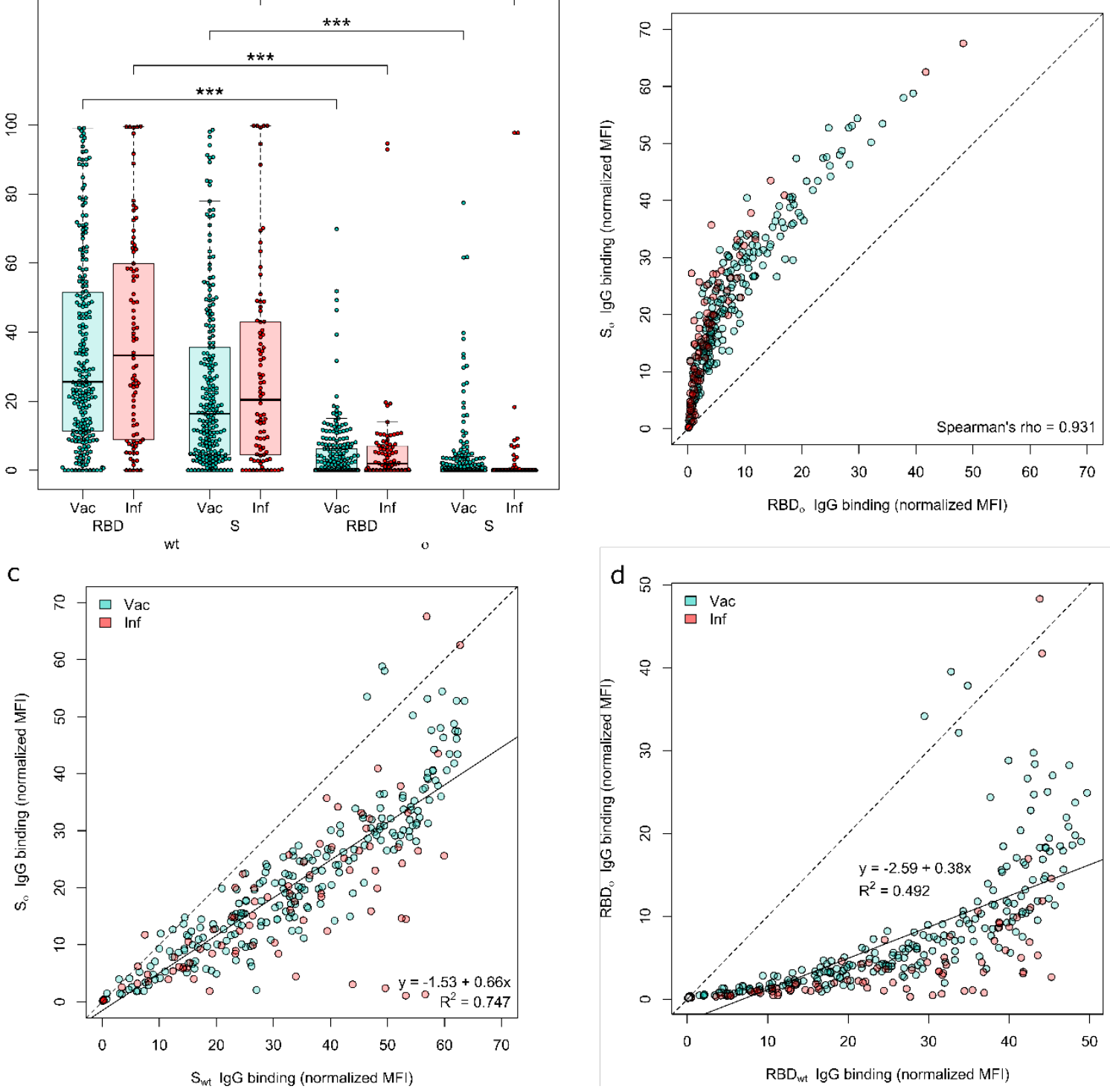

ACE2 binding inhibition (a) and IgG binding capacity (b-d) were compared for the Omicron RBD and S to the wild-type RBD and S. (a) Boxplot showing that ACE2 binding inhibition while significantly reduced for Omicron in general, is significantly reduced for the RBD compared to the Spike for both Vaccinated $(n-=226)$ and infected $(n=86)$ samples. Boxes represent the median, $25^{\text {th }}$ and $75^{\text {th }}$ percentiles, whiskers show the largest and smallest non-outlier values. Outliers were determined by 1.5 IQR. (b) Correlation analysis of IgG binding capacity for the Omicron spike 
medRxiv preprint doi: https://doi.org/10.1101/2021.12.30.21267519; this version posted January 1, 2022. The copyright holder for this preprint (which was not certified by peer review) is the author/funder, who has granted medRxiv a license to display the preprint in It is made available under a CC-BY-NC-ND 4.0 International license .

compared to the Omicron RBD. Spearman's rank was calculated to assess ordinal association between the variables. (c) Linear regression of IgG binding capacity for the Omicron Spike compared to wild-type Spike. (d) Linear regression of IgG binding capacity for the Omicron RBD compared to wild-type RBD. Statistical significance was calculated by Mann-Whitney $U$ with *** indicating a $p$-value $<0.001$. 
medRxiv preprint doi: $h t t p s: / / d o i . o r g / 10.1101 / 2021.12 .30 .21267519$; this version posted January 1 , 2022. The copyright holder for this preprint (which was not certified by peer review) is the author/funder, who has granted medRxiv a license to display the preprint in It is made available under a CC-BY-NC-ND 4.0 International license

Figure 3 - Differences in Omicron binding response among different populations of vaccinated and infected samples.

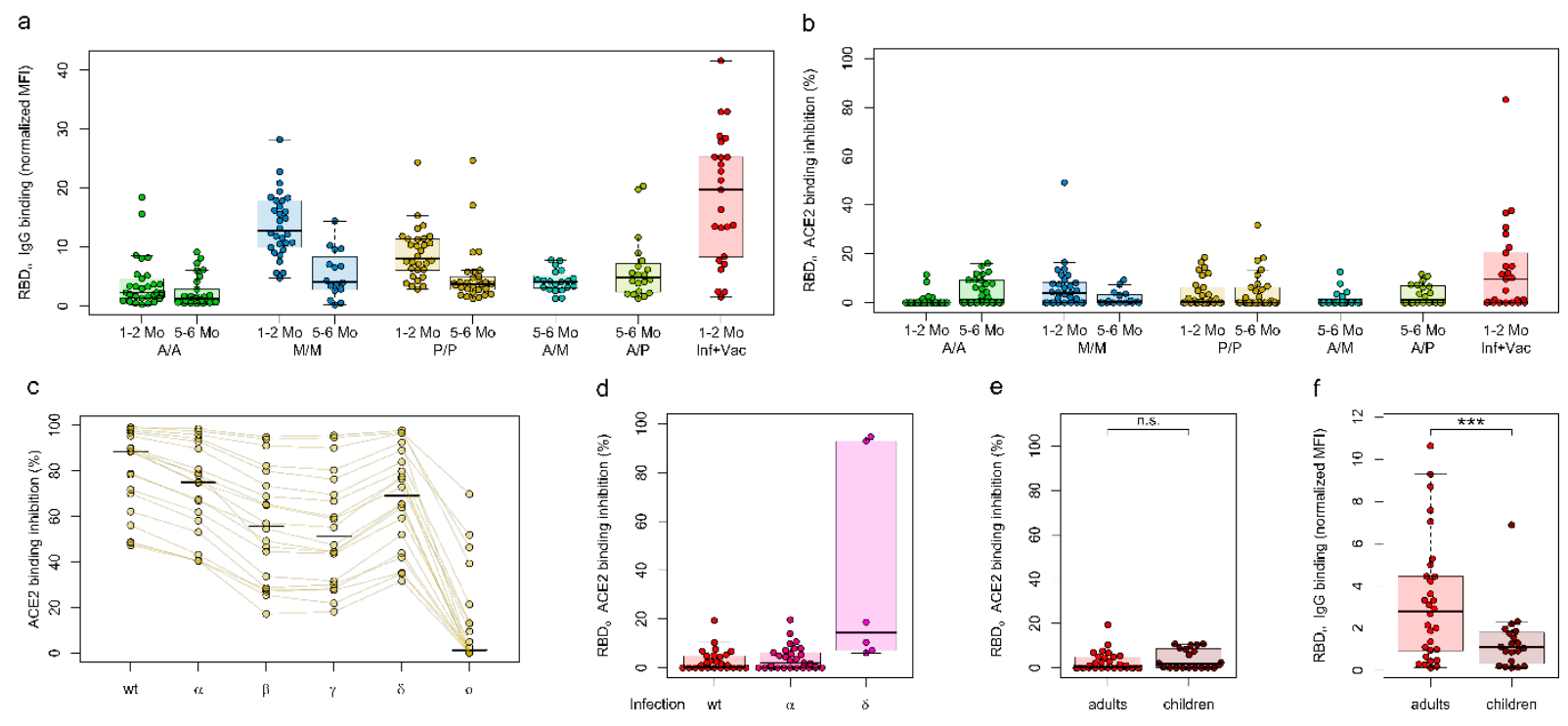

Binding response towards Omicron was analyzed by either MULTICOV-AB $(b, f)$ or RBDCoV-ACE2 ( $a, c-e)$. ( $a$ and $b)$ Differences in IgG binding and ACE2 binding inhibition by different vaccine schemes ( $\mathrm{n}=30$ for samples except for mRNA-1273 5-6 months $(n=16)$, heterologous vaccine schemes (both $n=20)$ and infected and vaccinated $(n=25)$. To determine the effect of time post-vaccination, samples from both 1-2 months and 5-6 months post-vaccination were included. (c) Changes in ACE2 binding response following the third dose of BNT162b2 for all variants of concern and wild-type $(n=20)$. For comparison, both 1-2 months and 5-6 months post second dose BNT162b2 can be found as Supplementary figure 3 and 4 (d) There are no differences in ACE2 binding inhibition towards Omicron for individuals infected with WT $(n=30)$, alpha $(n=30)$ or delta $(n=30)$. (e) Children $(n=20)$ have similar ACE2 binding inhibition towards Omicron compared to adults $(n=30)$ following a WT infection, while showing reduced IgG binding capacity (f). For panels $a, b$ and d-f, boxes represent the median, $25^{\text {th }}$ and $75^{\text {th }}$ percentiles, whiskers show the largest and smallest non-outlier values. Outliers were determined by $1.5 \mathrm{IQR}$. For panel c, 
medRxiv preprint doi: https://doi.org/10.1101/2021.12.30.21267519; this version posted January 1, 2022. The copyright holder for this preprint (which was not certified by peer review) is the author/funder, who has granted medRxiv a license to display the preprint in It is made available under a CC-BY-NC-ND 4.0 International license .

individual samples are highlighted by connected lines with bars representing medians. Statistical significance was calculated by Mann-Whitney $U$ were for e and $f$ with n.s. indicating a p-value $<0.05$ and ${ }^{* * *}$ indicating a $p$-value $<0.001$. 
medRxiv preprint doi: $h t t p s: / / d o i . o r g / 10.1101 / 2021.12 .30 .21267519$; this version posted January 1 , 2022. The copyright holder for this preprint (which was not certified by peer review) is the author/funder, who has granted medRxiv a license to display the preprint in It is made available under a CC-BY-NC-ND 4.0 International license .

\section{Tables}

Table 1 - Overview of sample characteristics for our study population.

\begin{tabular}{|c|c|c|c|c|c|c|}
\hline $\begin{array}{l}\text { Sample } \\
\text { type }\end{array}$ & $\begin{array}{l}\text { Sub- } \\
\text { group }\end{array}$ & $n$ & $\begin{array}{l}\text { Median } \\
\text { dT in } \\
\text { days } \\
\text { (IQR) }\end{array}$ & $\begin{array}{c}\text { Number } \\
\text { of } \\
\text { females } \\
(\%)\end{array}$ & $\begin{array}{l}\text { Median } \\
\text { age in } \\
\text { years } \\
\text { (IQR) }\end{array}$ & $\begin{array}{l}\text { History of } \\
\text { immuno- } \\
\text { suppressive } \\
\text { condition or } \\
\text { medication } \\
(\%)\end{array}$ \\
\hline \multirow[t]{4}{*}{ Infected } & $\begin{array}{l}\text { WT } \\
\text { (adults) }\end{array}$ & 30 & $\begin{array}{c}104 \\
(94-119)\end{array}$ & $14(47)$ & $\begin{array}{c}62 \\
(51-69)\end{array}$ & $0(0)$ \\
\hline & $\begin{array}{l}\text { WT } \\
\text { (children) }\end{array}$ & 20 & $\begin{array}{c}124 \\
(116-129)\end{array}$ & 7 (35) & $\begin{array}{c}11 \\
(7-14)\end{array}$ & $0(0)$ \\
\hline & Alpha & 30 & $\begin{array}{c}88 \\
(47-104)\end{array}$ & $12(40)$ & $\begin{array}{c}56 \\
(42-65) \\
\end{array}$ & $14(47)$ \\
\hline & Delta & 6 & $\begin{array}{c}18 \\
(10-23)\end{array}$ & $5(83)$ & $\begin{array}{c}65 \\
(56-73)\end{array}$ & $4(67)$ \\
\hline $\begin{array}{l}\text { Infected } \\
\text { and } \\
\text { vaccinated }\end{array}$ & & 25 & $\begin{array}{c}54 \\
(23-91)\end{array}$ & $16(64)$ & $\begin{array}{c}55 \\
(48-59)\end{array}$ & $1(4)$ \\
\hline \multirow[t]{9}{*}{ Vaccinated } & $\begin{array}{l}\mathrm{A} / \mathrm{A} \\
(1-2 \text { mo. })\end{array}$ & 30 & $\begin{array}{c}49 \\
(48-52) \\
\end{array}$ & $20(67)$ & $\begin{array}{c}64 \\
(60-66) \\
\end{array}$ & $2(7)$ \\
\hline & $\begin{array}{l}\mathrm{A} / \mathrm{A} \\
(4-6 \text { mo. })\end{array}$ & 30 & $\begin{array}{c}154 \\
(146-158)\end{array}$ & $23(77)$ & $\begin{array}{c}55 \\
(48-60)\end{array}$ & $0(0)$ \\
\hline & $\begin{array}{l}\mathrm{M} / \mathrm{M} \\
(1-2 \text { mo. })\end{array}$ & 30 & $\begin{array}{c}51 \\
(48-54)\end{array}$ & $20(67)$ & $\begin{array}{c}59 \\
(49-61)\end{array}$ & $1(3)$ \\
\hline & $\begin{array}{l}\mathrm{M} / \mathrm{M} \\
(4-6 \text { mo. })\end{array}$ & 16 & $\begin{array}{c}139 \\
(131-145)\end{array}$ & $9(56)$ & $\begin{array}{c}70 \\
(51-83)\end{array}$ & $1(6)$ \\
\hline & $\begin{array}{l}\mathrm{P} / \mathrm{P} \\
(1-2 \text { mo. })\end{array}$ & 30 & $\begin{array}{c}51 \\
(49-54)\end{array}$ & $20(67)$ & $\begin{array}{c}58 \\
(52-66)\end{array}$ & $1(3)$ \\
\hline & $\begin{array}{l}\mathrm{P} / \mathrm{P} \\
(4-6 \text { mo.) }\end{array}$ & 30 & $\begin{array}{c}152 \\
(141-160)\end{array}$ & $25(83)$ & $\begin{array}{c}38 \\
(30-53)\end{array}$ & $0(0)$ \\
\hline & $\mathrm{A} / \mathrm{M}$ & 20 & $\begin{array}{c}153 \\
(150-154)\end{array}$ & $16(80)$ & $\begin{array}{c}41 \\
(29-56) \\
\end{array}$ & $0(0)$ \\
\hline & $\mathrm{A} / \mathrm{P}$ & 20 & $\begin{array}{c}151 \\
(144-157)\end{array}$ & $19(95)$ & $\begin{array}{c}48 \\
(42-56)\end{array}$ & $0(0)$ \\
\hline & $\mathrm{P} / \mathrm{P} / \mathrm{P}$ & 20 & $\begin{array}{c}14 \\
(14-26.5)\end{array}$ & $13(65)$ & $\begin{array}{c}33 \\
(29-44)\end{array}$ & $2(12)^{*}$ \\
\hline Negative & & 15 & - & $8(53)$ & $\begin{array}{c}37 \\
(29-41)\end{array}$ & $0(0)$ \\
\hline
\end{tabular}

WT $=$ wild-type $(B \cdot 1$ isolate $) . A / A=$ two-dose $A Z D 1222 . M / M=$ two-dose mRNA-

1273. $P / P=$ two-dose $B N T 162 b 2 . A / M=$ first dose $A Z D 1222$, second dose mRNA1273. $A / P=$ first dose $A Z D 1222$, second dose $B N T 162 b 2 . P / P / P=$ three-dose BNT162b2. $n=$ number of samples. IQR = interquartile range. 
medRxiv preprint doi: https://doi.org/10.1101/2021.12.30.21267519; this version posted January 1, 2022. The copyright holder for this preprint (which was not certified by peer review) is the author/funder, who has granted medRxiv a license to display the preprint in It is made available under a CC-BY-NC-ND 4.0 International license.

Table 2 - Overview of antigens used in MULTICOV-AB and RBDCoV-ACE2.

\begin{tabular}{|c|c|c|c|}
\hline Antigen & Manufacturer & $\begin{array}{l}\text { Category } \\
\text { Number }\end{array}$ & Mutations covered \\
\hline Spike wild-type (B.1) & NMI & - & - \\
\hline RBD wild-type (B.1) & NMI & - & - \\
\hline S1 domain wild-type (B.1) & NMI & - & - \\
\hline S2 domain wild-type (B.1) & Sino Biological & 40590-V08B & - \\
\hline $\begin{array}{l}\text { Nucleocapsid wild-type } \\
\text { (B.1) }\end{array}$ & $\begin{array}{l}\text { Aalto } \\
\text { Bioreagents }\end{array}$ & $6404-b$ & - \\
\hline RBD alpha (B.1.1.7) & NMI & - & N501Y \\
\hline RBD beta (B.1.351) & NMI & - & K417N, E484K, N501Y \\
\hline RBD gamma (P1) & NMI & - & K417T, E484K, N501Y \\
\hline RBD delta (B.1.617.2) & NMI & - & L452R, T478K \\
\hline RBD omicron (B.1.529) & Sino Biological & $\begin{array}{l}\text { 40592- } \\
\text { V08H121 }\end{array}$ & $\begin{array}{l}\text { G339D, S371L, S373P, } \\
\text { S375F, K417N, N440K, } \\
\text { G446S, S477N, T478K, } \\
\text { E484A, Q493R, G496S, } \\
\text { Q498R, N501Y, Y505H }\end{array}$ \\
\hline Spike omicron (B.1.529) & Sino Biological & $\begin{array}{l}\text { 40589- } \\
\text { V08H26 }\end{array}$ & $\begin{array}{l}\text { A67V, del HV69/70, } \\
\text { T95I, G142D, del VYY } \\
\text { 143-145, del N211, } \\
\text { L212I, ins214EPE, } \\
\text { G339D, S371L, S373P, } \\
\text { S375F, K417N, N440K, } \\
\text { G446S, S477N, T478K, } \\
\text { E484A, Q493R, G496S, } \\
\text { Q498R, N501Y, Y505H, } \\
\text { T547K, H655Y, N679K, } \\
\text { P681H, N764K, } \\
\text { D796Y,F817P, N856K, } \\
\text { A892P, A899P, A942P, } \\
\text { Q954H, N969K, L981F, } \\
\text { K986P, V987P }\end{array}$ \\
\hline RBD lambda (C.37) & $\mathrm{NMI}$ & - & L452Q, F490S \\
\hline RBD mu (B.1.621) & NMI & - & R346K, E484K, N501Y \\
\hline
\end{tabular}

Mutations present within each antigen are provided. Where appropriate, the manufacturers category number is provided. For details on the NMI antigen production, please consult $(20,21,25)$. 